\title{
Effect of Nitrogen, Phosphorus and Potassium Fertilizers as Nano and Regular Mineral on Maize Growth (Zea mays L.) Plants Grown in Saline-Sodic Soil, at North Sinai, Egypt
}

\author{
Sara El-Sayed El-Sayed Fouda ${ }^{1}$
}

\begin{abstract}
Field experiments were conducted to compare nano NPK fertilizers with ordinary mineral NPK fertilizers on maize (Zea mays L. Triple hybrid Giza 320) grown on a saline sodic sandy loam soil. Two experiments were conducted on 2018 and 2019 seasons at Romanh Village, North Sinai Egypt. The design was a randomized complete block, factorial (split plot). Factor1: Source (i.e. mineral ' $S_{1}$ ' and nano 'S2'). Factor2 Dose "rate" (i.e. $\mathrm{kgha}^{-1}$ NPK of $0 / 0 / 0$, $120 / 180 / 60 ; 180 / 36 / 120$ and $240 / 72 / 180$ for $D_{0}, D_{1}, D_{2}$ and $D_{3}$ respectively. The fertilized treatments using the nano forms were much superior then those of the regular mineral ones. Superiority was up to the followings for each 8 and $12 \%$ for grain and straw yields respectively. For the other traits, superiorities for uptakes were up to $29 \%$ (straw N) 3\% (grains N), 41\% (straw P), $7 \%$ (grain P), $27 \%$ (straw K) and 34\% (grain K.). Fertilization enhanced plants to sustain salinity stress conditions. The mineral fertilization caused plants to accumulate more proline " $\mathrm{g}$ $\mathrm{kg}^{-1}$ fresh matter": average of $\mathbf{4 4 . 3}$ for the mineral and 27.4 for the nano.
\end{abstract}

Key words: Maize, Saline-sodic Soil, nano fertilizers and regular mineral NPK.

\section{INTRODUCTION}

Maize as one of the important cereal crops in Egypt needs high rate of $\mathrm{N}$-application reached to $714 \mathrm{~kg}$ urea $\mathrm{ha}^{-1}$ in normal soils (Nofal, 2003). El- Bana and Gomaa (2000) obtained increases in grain yield by ncreasing levels of nitrogen from 238 to $286 \mathrm{~kg} \mathrm{~N} \mathrm{ha}^{-1}$. Soil salinity is a major concern in agriculture all over the world because it affects almost all plant functions. More than $6 \%$ of the world land and one third of the world irrigated land are adversely affected by soil salinity (FAO, 2008). It has been reported that coastal regions of Bangladesh are very much lower in soil fertility than the other parts of the country (Haque, 2006). Accumulation of proline in plant tissues helps in alleviating the negative effect of salinity stress on plants (Moussa and Abdel-Aziz, 2008).

Chemical compounds are increasingly used all over the world to enhance crop productivity. Mineral fertilizers are among such compounds. Nitrogen fertilization plays a key role in plant growth, yield and hence crop water productivity (Ahmed et al., 2014). The most widely used water soluble source of nitrogen fertilizers is urea $\left(460 \mathrm{~g} \mathrm{~N} \mathrm{~kg}^{-}\right.$ $\left.{ }^{1}\right)$. However, it is subject to heavy losses through leaching but can be used with lower leaching loss if modified by treatment with hydroxyapatite particles (Subbaiya et al., 2012). Phosphorus is a major plant nutrient usually supplied in many different forms (Abou El-Yazeid and Abou-Aly, 2011). Potassium is another major essential nutrient (Chandra, 1989). Heavy application rates of chemical fertilizers result in many serious environmental problems (Abdel Wahab et al., 2017). A number of up-to-date methods and techniques in fertilization are recently being used in order to avoid environmental pollution and relieve heavy dependence of chemical fertilization. On of such methodologies and techniques is the use of nano fertilization (Ditta 2012). Nanotechnology relates to using materials, systems and processes which operate at a scale of 100 nanometers (nm) or less (Srilatha 2011). One of the most important uses of nanotechnology is nano-fertilization which enhances the ability of plants to absorb nutrients (Mousavi and Rezai 2011, Srilatha 2011 and Ditta 2012).

The aim of the current study was to investigate the effect of nano and ordinary methods of NPK fertilizer on maize grown on a saline sodic soil.

\section{MATERIALS AND METHODS}

A filed experiment on maize (Zea mays L. Triple hybrid Giza 320) was conducted on a saline-sodic sandy loam soil at Romanh Village, North Sinai Governorate, Egypt $\left(31.0^{\circ} \mathrm{N} 32.41^{\circ} \mathrm{E}\right)$ for two successive growing seasons of 2018 and 2019. The design was randomized complete block (factorial) with three replicates. Factor 1 was the $\mathrm{N}$ - Source (i.e. mineral ' $\mathrm{S}_{1}$ ' and nano ' $\mathrm{S}_{2}$ ') while factor2 was the dose "rate' (i.e. $\mathrm{kg} \mathrm{ha}^{-1} \mathrm{NPK}$ of $0 / 0 / 0,120 / 180 / 60 ; 180 / 36 / 120$ and $240 / 72 / 180$ for $D_{0}$, $\mathrm{D}_{1}, \mathrm{D}_{2}$ and $\mathrm{D}_{3}$ respectively.

\section{Preparation of nano Fertilizers}

According to De Moura et al. (2008) and Corradini et al. (2010), chitosan polymerizing meth-acrylic acid (CS-PMAA) nanoparticles were prepared by polymerizing the meth-acrylic acid (MAA) in s chitosan

DOI: 10.21608/asejaiqjsae.2021.166115

${ }^{1}$ Soil Science Department, Faculty of Agriculture, Zagazig University, Zagazig, Egypt.

Corresponding author: Tel.: +201096175175

E-mail address:sarafouda_2002@yahoo.com

Received March 24, 2021, Accepted, April 24, 2021. 
solution (CS) as a carrier coated in a buffer solution for $5 \mathrm{hrs}$ in a two-step process. In the first step, $0.23 \mathrm{~g}$ chitosan was dissolved in meth-acrylic acid solution $(0.5 \%, \mathrm{v} / \mathrm{v})$ for $18 \mathrm{hrs}$ using a magnetic stirrer. In the second step, with continued stirring, $0.2 \mathrm{mmol}$ of $\mathrm{K}_{2} \mathrm{~S}_{2} \mathrm{O}_{8}$ were added until the solution became clear. Polymerization was subsequently carried out at $75^{\circ} \mathrm{C}$ using a magnetic stirrer for $4 \mathrm{~h}$ leading to formation of nano-particle solution, then centrifuged at $500 \mathrm{rpm}$ for 30 min., then cooled in an ice bath. Urea, $\mathrm{NH}_{4} \mathrm{NO}_{3}, \mathrm{Ca}$ $\left(\mathrm{H}_{2} \mathrm{PO}_{4}\right)_{2}$ and $\mathrm{KCl}$ were used separately. The loading of $\mathrm{N}$ salt in chitosan nanoparticles was obtained by dissolving of $2 \mathrm{~m}$ into $100 \mathrm{~mL}$ of chitosan nanoparticle solution under magnetic stirring for $8 \mathrm{hrs}$ at $25^{\circ} \mathrm{C}$; subsequently dried at $50{ }^{\circ} \mathrm{C}$ for $72 \mathrm{hrs}$. The following concentrations of $1000 \mathrm{mg} \mathrm{kg}^{-1}$ of $\mathrm{N}, \mathrm{P}$ and $\mathrm{K}$ were finally obtained in each solution. The resulting solutions had a $\mathrm{pH}$ of 5.50. Nano fertilizers were sprayed 3 times at 35,50 and 75 days after seeding (DAS) at a rate of 20L/950L water ha-1.

\section{Agronomic operations and analytical methods:}

Sowing was done on $10^{\text {th }}$ and $12^{\text {th }}$ of May 2018 and 2019 , or the first and second seasons respectively. Plot size was $50 \mathrm{~m}^{2}(5 \times 10 \mathrm{~m})$ having 14 ridges of $5 \mathrm{~m}$ in length and $0.7 \mathrm{~m}$ in width, with two plants hill- ${ }^{-1}$ and 20 $\mathrm{cm}$ between hills. Nitrogen fertilizer was applied as urea $\left(460 \mathrm{~g} \mathrm{~N} \mathrm{~kg}^{-1}\right)$ in 3 equal splits at seeding, then 30 and 50 days after. $\mathrm{P}$ was added as superphosphate fertilizer $\left(68 \mathrm{~g} \mathrm{P} \mathrm{kg}^{-1}\right)$ during seedbed preparation and potassium was as potassium sulphate $\left(420 \mathrm{~g} \mathrm{~K} \mathrm{~kg}^{-1}\right)$ in two equal splits 30 and 45 days after seeding.

Agricultural practices were carried out as recommended by the Ministry of Agriculture. Crop maturity occurred on the $15^{\text {th }}$ and $27^{\text {th }}$ September for 2018 and 2019 seasons, respectively. Maize ears were collected on the $20^{\text {th }}$ October. Total chlorophyll content was determined as described by Witham et al (1971). Total proline content was determined as described by Bates et al. (1973) and oil content in seeds was determined using the Soxhelt method (AOAC, 1990). Plant samples were subjected to digested by a mixture of conc. $\mathrm{H}_{2} \mathrm{SO}_{4}$ and $\mathrm{HClO}_{4}$ acids after drying in an oven at $70^{\circ} \mathrm{C}$ (Ryan et al. (1996). Protein in plant was calculated by multiplying grain $\mathrm{N}$ contents by 6.25 (FAO, 2003). Main soil properties were determined according to methods cited by Black et al., (1982) and the results were shown in Table 1.

\section{RESULTS AND DISCUSSION}

Results show differences between sources and rates with regard to different parameters, yields and yield components. as shown by Tables 2 to 3 . Differences between the non-fertilized nano and the nonfertilized mineral for all results and parameters were not statistically significant.

\section{Plant attributes (Table2):}

Table 2 showed that plant height $(\mathrm{cm})$ ranged from 94.3 due to nano non-fertilized $\mathrm{S}_{2} \mathrm{D}_{0}$ to as high as 170.6 by the nano-highest rate $\left(\mathrm{S}_{2} \mathrm{D}_{3}\right)$ with an increase of $80.9 \%$. Increased rate of application was associated with increased plant height averaging as high as 65.5\% caused by $\mathrm{D}_{3}$. The increase was particularly evident where the nano source was used. The nano source surpassed the regular mineral one by an average of 17.6 $\%$ and such superiority occurred where fertilizers were applied. Nano forms surpassed the mineral one by as average of $17.6 \%$.

As shown in Table 2 ear length $(\mathrm{cm})$ was lowest (15.95) by the mineral non-fertilized $S_{1} D_{0}$ highest by the nano-highest rate $\left(\mathrm{S}_{2} \mathrm{D}_{3}\right)$ which caused $101 \%$ increase.

Table 1. Physical and chemical properties of soil of the study in Romanh, North Sinai.

\begin{tabular}{|c|c|c|c|c|c|c|c|c|}
\hline $\begin{array}{l}\text { Coarse sand } \\
(\%)\end{array}$ & $\begin{array}{c}\text { Fine sand } \\
(\%)\end{array}$ & $\begin{array}{l}\text { Silt } \\
(\%)\end{array}$ & $\begin{array}{l}\text { Clay } \\
(\%)\end{array}$ & \multicolumn{2}{|c|}{ Texture } & $\begin{array}{c}\text { O.M } \\
\left(\mathrm{gkg}^{-1}\right)\end{array}$ & SAR & $\begin{array}{c}\mathrm{CaCO}_{3} \\
\left(\mathrm{gkg}^{-1}\right)\end{array}$ \\
\hline 8.90 & 60.55 & 12.22 & 18.33 & \multicolumn{2}{|c|}{ Sandy loam } & 5.7 & 14.4 & 105.5 \\
\hline \multirow{2}{*}{ pH $(1: 2.5)$} & EC & \multicolumn{7}{|c|}{ Soluble ion $\left(\operatorname{mmolc} L^{-1}\right)$} \\
\hline & $\left(\mathrm{dS} \mathrm{m}^{-1}\right)$ & $\mathbf{C a}^{++}$ & $\mathbf{M g}^{++}$ & $\mathrm{Na}^{+}$ & $\mathbf{K}^{+}$ & $\mathrm{HCO}_{3}^{-}$ & $\mathrm{Cl}^{-}$ & $\mathrm{SO}_{4}^{--}$ \\
\hline 8.12 & 9.54 & 13.9 & 20.8 & 60.0 & 0.8 & 10.9 & 52.4 & 32.2 \\
\hline \multicolumn{9}{|c|}{ Available nutrients $\left(\mathrm{mg} \mathrm{kg}^{-1}\right)$} \\
\hline $\mathbf{N}$ & $\mathbf{P}$ & $\mathbf{K}$ & \multicolumn{2}{|c|}{$\mathbf{F e}$} & \multicolumn{2}{|c|}{ Mn } & \multicolumn{2}{|c|}{$\mathbf{Z n}$} \\
\hline 40 & 4 & 185 & \multicolumn{2}{|c|}{2.38} & \multicolumn{2}{|c|}{1.50} & \multicolumn{2}{|c|}{0.58} \\
\hline Notes: & \multicolumn{8}{|c|}{$\begin{array}{l}\text { Extracts for available nutrients: } \mathrm{K}_{2} \mathrm{SO}_{4}(\mathrm{~N}) \text {; Na bicarbonate }(\mathrm{P}) \text {; } \mathrm{NH}_{4} \mathrm{Ac}(\mathrm{K}) \text {; DTPA }(\mathrm{Fe}, \mathrm{Mn}, \mathrm{Zn}) \\
\text { No soluble } \mathrm{CO}_{3}{ }^{-} \text {was detected }\end{array}$} \\
\hline
\end{tabular}


Table 2. yield component and yield of maize grown in a saline sodic soil as affected by $\mathbf{N}$-source and rate

\begin{tabular}{|c|c|c|c|c|c|c|c|c|c|c|}
\hline \multirow[t]{2}{*}{ NPK-source, $S$} & \multicolumn{10}{|c|}{ NPK fertilization rate (D) } \\
\hline & $\mathbf{D}_{0}$ & $\mathbf{D}_{1}$ & $\mathbf{D}_{2}$ & $\mathbf{D}_{3}$ & Mean & $\mathbf{D}_{0}$ & $\mathbf{D}_{1}$ & $\mathbf{D}_{2}$ & $\mathbf{D}_{3}$ & Mean \\
\hline & \multicolumn{5}{|c|}{ Plant height $(\mathrm{cm})$} & \multicolumn{5}{|c|}{ Ear length $(\mathrm{cm})$} \\
\hline Mineral, $S_{1}$ & 95.6 & 112.6 & 123.1 & 143.5 & $118.7 \mathrm{~b}$ & 15.95 & 22.34 & 23.56 & 24.85 & $21.68 \mathrm{~b}$ \\
\hline Nano, $\mathrm{S}_{2}$ & 94.3 & 138.5 & 155.0 & 170.6 & $139.6 \mathrm{a}$ & 16.23 & 26.63 & 30.14 & 32.25 & $26.31 \mathrm{a}$ \\
\hline Mean & $94.9 \mathrm{~d}$ & $125.6 \mathrm{c}$ & $139.1 \mathrm{~b}$ & $157.1 \mathrm{a}$ & & $16.09 \mathrm{~d}$ & $24.49 \mathrm{c}$ & $26.85 b$ & $28.55 \mathrm{a}$ & \\
\hline \multirow[t]{3}{*}{ F-test } & S: & $* *$ & D: & $* *$ & & S: & $* *$ & D: & $* *$ & \\
\hline & & & $\mathrm{SD}: * *$ & & & & & $\mathrm{SD}: * *$ & & \\
\hline & \multicolumn{5}{|c|}{ weight of ears (g plant $\left.{ }^{-1}\right)$} & \multicolumn{5}{|c|}{ Grains weight ear ${ }^{-1}(\mathrm{~g})$} \\
\hline $\mathrm{S}_{1}$ & 159.1 & 236.0 & 245.2 & 248.0 & $222.1 b$ & 110.4 & 123.0 & 132.0 & 135.0 & $125.1 \mathrm{~b}$ \\
\hline $\mathrm{S}_{2}$ & 159.8 & 244.0 & 251.3 & 255.0 & $227.5 \mathrm{a}$ & 109.5 & 137.0 & 144.2 & 150.0 & $135.2 \mathrm{a}$ \\
\hline Mean & $159.5 \mathrm{~d}$ & $240.0 \mathrm{c}$ & $248.3 b$ & $251.5 \mathrm{a}$ & & $109.9 \mathrm{~d}$ & $130.0 \mathrm{c}$ & $138.1 b$ & $142.5 \mathrm{a}$ & \\
\hline \multirow{3}{*}{ F-test } & S: & $* *$ & $\mathrm{D}:$ & $* *$ & & S: & $* *$ & $\mathrm{D}:$ & $* *$ & \\
\hline & & & $\mathrm{SD}: * *$ & & & & & SD: $* *$ & & \\
\hline & \multicolumn{5}{|c|}{ 100-grain weight (g) } & \multicolumn{5}{|c|}{ Straw yield $\left(\mathrm{Mg} \mathrm{ha}^{-1}\right)$} \\
\hline $\mathrm{S} 1$ & 25.63 & 30.15 & 32.18 & 32.99 & $30.24 b$ & 2.679 & 4.410 & 5.007 & 5.022 & $4.279 \mathrm{~b}$ \\
\hline $\mathrm{S} 2$ & 25.84 & 33.14 & 34.56 & 36.20 & $32.44 \mathrm{a}$ & 2.726 & 5.381 & 5.595 & 5.976 & $4.920 \mathrm{a}$ \\
\hline Mean & $25.74 \mathrm{c}$ & $31.65 b$ & $33.37 \mathrm{a}$ & $34.60 \mathrm{a}$ & & $2.703 b$ & $4.895 \mathrm{a}$ & $5.300 \mathrm{a}$ & $5.500 \mathrm{a}$ & \\
\hline \multirow{3}{*}{ F-test } & S: & $* *$ & D: & $* *$ & & $\mathrm{~S}:$ & $*$ & & $* *$ & \\
\hline & \multirow{2}{*}{\multicolumn{5}{|c|}{ Grain yield $\left(\mathrm{Mg} \mathrm{ha}^{-1}\right)$}} & SD: & \multicolumn{4}{|c|}{ NS } \\
\hline & & & & & & & & & & \\
\hline $\mathrm{S} 1$ & 2.338 & 3.079 & 3.426 & 3.691 & 3.133 & & & & & \\
\hline S2 & 2.230 & 3.310 & 3.405 & 3.719 & 3.166 & & & & & \\
\hline Mean & $2.284 b$ & $3.195 \mathrm{a}$ & $3.416 a$ & $3.705 a$ & & & & & & \\
\hline F-test & S: & NS & $\begin{array}{c}\text { D: } \\
\text { SD: NS }\end{array}$ & $* *$ & & & & & & \\
\hline
\end{tabular}

Notes:1. Rates of NPK are ' $\mathrm{kgha}^{-1}$ ': 0/0/0, (120/18/60), (180/36/120) and (240/72/180) for $\mathrm{D}_{0} \mathrm{D}_{1}, \mathrm{D}_{2}$ and $\mathrm{D}_{3}$ respectively. 2. Mineral sources for NPK are urea, K-sulphate and Ca-superphosphate

Increasing the rate of fertilization was associated with increased ear height with an average of as high as $77.4 \%$ caused by $\mathrm{D}_{3}$ and such a pattern was particularly evident under conditions of the nano source which surpassed the mineral one $21.4 \%$ and such superiority was more evident where plants were fertilized.

Weight of ears per plant $\left(g_{\text {plant }}{ }^{-1}\right)$ was the lowest due to 159.1 by the mineral-nonfertilized $\left(\mathrm{S}_{1} \mathrm{D}_{0}\right)$ and highest by the nano-highest rate $\left(\mathrm{S}_{2} \mathrm{D}_{3}\right)$ which caused $60.3 \%$ increase. Increased ear weight was with increased fertilization and the increased fertilization was as high as $60.0 \%$ on average. The nano source surpassed the mineral one by $2.4 \%$ the superiority was more evident where plants were fertilized.
Grains weight per ear $\left(\mathrm{g} \mathrm{ear}^{-1}\right)$ followed a pattern similar to that of the ear weight. It was lowest of 109.5 by the $S_{1} D_{0}$ and highest by the $S_{2} D_{3}$ which caused $38.0 \%$ increase. The increase in grain weight was parallel with the increase in fertilization rate and was as high as $30.1 \%$ on average at the highest rate. The nano source surpassed the mineral one by $8.1 \%$ and the superiority was more evident where plants were fertilized.

The 100-grain weight $(\mathrm{g})$ ranged from 25.63 by the mineral non-fertilized $S_{1} D_{0}$ to as high as 36.20 by the $\mathrm{S}_{2} \mathrm{D}_{2}$ nano-highest rate with an increase of $41.2 \%$. Increased application was associated with increased 100 -grain weight. The highest $\mathrm{D}_{3}$ rate caused an average of $34.4 \%$ in the 100 -grain weight. The nano source 
surpassed the mineral one by $7.3 \%$ and the surpass occurred only where fertilizers were given.

\section{Grains and straw yields ( $\left.\mathrm{Mg} \mathrm{ha}^{-1}\right)$ :}

Grain yield followed a pattern similar to that of the above mentioned plant attributes. It was lowest of 2.230 by the $\mathrm{S}_{2} \mathrm{D}_{0}$ and highest by the $\mathrm{S}_{2} \mathrm{D}_{3}$ which caused $59.1 \%$ increase. The increase was parallel with the increase in fertilization rate reaching as high as $49.1 \%$ on average at the highest rate. The nano source surpassed the mineral one by an average of $18.7 \%$; and the superiority was more evident where plants were fertilized.

\section{Straw yield:}

The straw yield $\left(\mathrm{Mg} \mathrm{ha}^{-1}\right)$ followed a pattern similar to the grain yield. It was lowest of 2.670 by the $\mathrm{S}_{1} \mathrm{D}_{0}$ and highest by the $\mathrm{S}_{2} \mathrm{D}_{3}$ which caused $23.1 \%$ increase. The increase was progressive as that of the increase in fertilization and reached as high as $103 \%$ on average at the highest rate. The nano source surpassed the mineral one by an average of $19.0 \%$; and the difference was more evident where plants were fertilized.

\section{Assessment of response to growth and productivity of plant.}

The positive response obtained by application of fertilizers which is caused by the significant increases caused by fertilization, particularly with the progressive increase in the rate, is an indication of the need for fertility enhancement of the soil. The evident superiority of the nano source over the ordinary mineral source is a demonstration of the high efficiency of former over the latter. Subbaiya et al. (2012) reported that nano fertilizers on improved seed germination, which reflected positively on all crop traits. Other researchers (Ekinci et al. ,2014, Abdel Wahab et al. 2019 and Merghany et al. 2019) found that application of macronutrients to maize caused high increases in values of traits and yields of maize particularly when applied in nano forms.

Chlorophyll, proline, oil, and protein in maize grains (Table 3)

As shown in Table 3, Chlorophyll contents was lowest (8.23) by the non-fertilized mineral $S_{1} D_{0}$ and highest by the highest fertilized nano $\mathrm{S}_{2} \mathrm{D}_{3}$ which caused an increase of $147 \%$.

Table 3. Chlorophyll, proline, oil and protein in maize as affected by $\mathrm{N}$-sources and rates

\begin{tabular}{|c|c|c|c|c|c|c|c|c|c|c|}
\hline \multirow[t]{2}{*}{ NPK-source, $S$} & \multicolumn{10}{|c|}{ NPK fertilization dose (D) } \\
\hline & $\mathbf{D}_{\mathbf{0}}$ & $\mathbf{D}_{1}$ & $\mathbf{D}_{2}$ & $\mathbf{D}_{3}$ & Mean & $\mathbf{D}_{\mathbf{0}}$ & $\mathbf{D}_{1}$ & $\mathbf{D}_{2}$ & $\mathbf{D}_{3}$ & Mean \\
\hline & \multicolumn{5}{|c|}{ Chlorophyll (mg g ${ }^{-1}$ f.w) } & \multicolumn{5}{|c|}{ Proline (mg g g $^{-1}$ f.w) } \\
\hline Mineral, S1 & 8.23 & 12.14 & 14.56 & 16.32 & $12.81 \mathrm{~b}$ & 43.63 & 40.34 & 43.15 & 39.52 & $41.66 a$ \\
\hline Nano, S2 & 8.52 & 13.68 & 17.52 & 20.36 & $15.02 \mathrm{a}$ & 43.25 & 32.10 & 29.85 & 20.14 & $31.34 \mathrm{~b}$ \\
\hline Mean & $8.38 \mathrm{~d}$ & $12.91 \mathrm{c}$ & $16.04 b$ & $18.34 \mathrm{a}$ & & $43.44 \mathrm{a}$ & $36.22 b$ & $35.60 \mathrm{c}$ & $29.83 d$ & \\
\hline \multirow[t]{3}{*}{ F-test } & S: & $* *$ & D: & $* *$ & & S: & $* *$ & $\mathrm{D}:$ & $* *$ & \\
\hline & \multicolumn{5}{|c|}{ SD: NS } & \multicolumn{5}{|c|}{ SD: $* *$} \\
\hline & \multicolumn{5}{|c|}{ Oil content $\left(\mathrm{g} \mathrm{kg}^{-1}\right)$} & \multicolumn{5}{|c|}{ Grain protein content $\left(\mathrm{g} \mathrm{kg}^{-1}\right)$} \\
\hline S1 & 48.6 & 53.4 & 58.6 & 59.8 & 55.1 & 73.7 & 90.6 & 92.5 & 94.4 & 87.8 \\
\hline S2 & 44.4 & 55.9 & 59.8 & 61.2 & 55.4 & 75.0 & 91.2 & 95.0 & 96.9 & 89.5 \\
\hline Mean & $46.5 b$ & $54.7 \mathrm{a}$ & $59.2 \mathrm{a}$ & $60.5 \mathrm{a}$ & & $74.4 \mathrm{~b}$ & $90.9 \mathrm{a}$ & $93.8 \mathrm{a}$ & $95.7 \mathrm{a}$ & \\
\hline \multirow{2}{*}{ F-test } & S: & NS & D: & $* *$ & & S: & NS & D: & $* *$ & \\
\hline & \multicolumn{5}{|c|}{ SD: NS } & \multicolumn{5}{|c|}{ SD: NS } \\
\hline \multicolumn{11}{|c|}{ Protein yield (kg ha-1) } \\
\hline $\mathrm{S} 1$ & 173 & 279 & 317 & 348 & 279 & & & & & \\
\hline S2 & 167 & 302 & 323 & 360 & 288 & & & & & \\
\hline Mean & $170 \mathrm{~b}$ & $291 \mathrm{a}$ & $320 \mathrm{a}$ & $354 \mathrm{a}$ & & & & & & \\
\hline F-test & S: & NS & D: & $* *$ & & & & & & \\
\hline & & & SD: $N$ & & & & & & & \\
\hline
\end{tabular}

See footnote of Table 2 . 
The increase was progressive in line with the increase in fertilization and reached as high as $119 \%$ on average at the highest rate. The nano source surpassed the mineral one by an average of $17.3 \%$; and the difference was more evident where plants only under fertilization. $\mathrm{N}$ and $\mathrm{K}$ are essential for photosynthesis particularly with nano systems (Abdel Wahab et al., 2019).

\section{Contents of proline}

Contents of proline followed a general trend of decrease due to application of fertilizers (Table 3). The nonfertilized contained about $43 \mathrm{mg}$ proline $\mathrm{g}^{-1}$ fresh weight, while most of the other treatments contained lower contents. A high proline in plant indicates a stress caused by salinity (Moussa and Abdel-Aziz 2008). The soil was saline and results show a steady decrease in proline contents with increased application of fertilizers. The decreases averaged 5.1, 18.0 and $68.7 \%$ caused by $D_{1}, D_{2}$ and $D_{3}$ respectively. This may indicate that fertilization contributed in alleviating the stress of soil salinity.

The mineral source surpassed the nano one by an average of $32.5 \%$; and the difference occurred only under fertilization indicating a positive role of the nano source. Proline is a major source of energy inducing salinity tolerance ( $\mathrm{Gad} 2005)$.

\section{Contents of oil $\left(\mathrm{g} \mathrm{kg}^{-1}\right)$ :}

Oil contents was lowest (48.6) by the nonfertilized mineral $\mathrm{S}_{1} \mathrm{D}_{0}$ and highest. 61.2 by the highest fertilized nano $\mathrm{S}_{2} \mathrm{D}_{3}$ which caused an increase of $28.9 \%$ increase (Table 3). The increase was progressive in line with the increase in fertilization and reached as high as $30.1 \%$ on average at the $D_{3}$ rate. The two sources were rather similar in their effect. Fertilizer NPK application increases oil contents in maize seeds (El- Shimy et al. 2006 and Hussein, 2007).

\section{Contents of protein in grains}

As shown in Table 3 protein ranged from 73.7 by the nonfertilized mineral $\mathrm{S}_{1} \mathrm{D}_{0}$ to 96.9 by the highest fertilized nano $\mathrm{S}_{2} \mathrm{D}_{3}$ i.e. an increase of $31.5 \%$. The increase was associated with the increased fertilization. The average increase was as high as $28.6 \%$ at the highest rate. The two sources were rather similar in effect.

Table 4. Macronutrients content $\left(\mathrm{g} \mathrm{kg}^{-1}\right)$ in straw and grains of maize.

\begin{tabular}{|c|c|c|c|c|c|c|c|c|c|c|}
\hline \multirow[t]{2}{*}{ NPK-source, } & \multicolumn{10}{|c|}{ NPK fertilization dose (D) } \\
\hline & $\mathbf{D}_{0}$ & $\mathbf{D}_{1}$ & $\mathbf{D}_{2}$ & $\mathbf{D}_{3}$ & Mean & $\mathbf{D}_{0}$ & $D_{1}$ & $\mathbf{D}_{2}$ & D3 & Mean \\
\hline \multicolumn{11}{|c|}{ N-content } \\
\hline & \multicolumn{5}{|c|}{ In Straw } & \multicolumn{5}{|c|}{ In Grains } \\
\hline Mineral, S1 & 16.5 & 19.8 & 20.3 & 20.5 & $19.3 \mathrm{~b}$ & 11.8 & 14.5 & 14.8 & 15.1 & 14.1 \\
\hline Nano, S2 & 16.6 & 21.4 & 21.9 & 22.3 & $20.6 \mathrm{a}$ & 11.6 & 14.6 & 15.2 & 15.5 & 14.2 \\
\hline Mean & $16.6 \mathrm{~b}$ & $20.6 \mathrm{a}$ & $21.1 \mathrm{a}$ & $21.4 \mathrm{a}$ & & $11.7 \mathrm{~b}$ & $14.6 \mathrm{a}$ & $15.0 \mathrm{a}$ & $15.3 \mathrm{a}$ & \\
\hline F-test & S: & $* *$ & $\begin{array}{c}\text { D: } \\
\text { SD: NS }\end{array}$ & $* *$ & & S: & NS & $\begin{array}{c}\text { D: } \\
\text { D: NS }\end{array}$ & $* *$ & \\
\hline \multicolumn{11}{|c|}{ P- content } \\
\hline & \multicolumn{5}{|c|}{ In Straw } & \multicolumn{5}{|c|}{ In Grains } \\
\hline S1 & 2.20 & 2.50 & 2.80 & 3.20 & $2.68 \mathrm{~b}$ & 3.40 & 3.90 & 4.40 & 4.80 & 4.13 \\
\hline S2 & 2.15 & 2.90 & 3.40 & 3.80 & $3.06 \mathrm{a}$ & 3.60 & 4.20 & 4.80 & 5.10 & 4.43 \\
\hline Mean & $2.18 \mathrm{~d}$ & $2.70 \mathrm{c}$ & $3.10 \mathrm{~b}$ & $3.50 \mathrm{a}$ & & $3.50 \mathrm{~b}$ & $4.05 \mathrm{ab}$ & $4.60 \mathrm{a}$ & $4.95 \mathrm{a}$ & \\
\hline F-test & S: & $* *$ & $\begin{array}{c}\text { D: } \\
\text { SD: NS }\end{array}$ & $* *$ & & S: & NS & $\begin{array}{c}\text { D: } \\
\text { D: NS }\end{array}$ & $*$ & \\
\hline \multicolumn{11}{|c|}{ K-content } \\
\hline & \multicolumn{5}{|c|}{ In Straw } & \multicolumn{5}{|c|}{ In Grains } \\
\hline S1 & 21.0 & 22.3 & 22.5 & 22.8 & 22.2 & 8.90 & 9.60 & 10.2 & 10.6 & $9.83 b$ \\
\hline S2 & 21.6 & 23.1 & 23.8 & 24.4 & 23.2 & 8.60 & 10.4 & 10.8 & 11.2 & $10.3 \mathrm{a}$ \\
\hline Mean & 21.3 & 22.7 & 23.2 & 23.6 & & $8.75 \mathrm{~b}$ & $10.0 \mathrm{ab}$ & $10.5 \mathrm{a}$ & $10.9 \mathrm{a}$ & \\
\hline F-test & S: & NS & $\begin{array}{c}\text { D: } \\
\text { SD: NS }\end{array}$ & NS & & $\begin{array}{c}\text { S: } \\
\text { SD: }\end{array}$ & $*$ & D: & $*$ & \\
\hline
\end{tabular}

See footnote of Table 2 
Table 5. Micronutrients content $\left(\mathrm{mg} \mathrm{kg}^{-1}\right)$ in straw and grains of maize plants

\begin{tabular}{|c|c|c|c|c|c|c|c|c|c|c|}
\hline NPK-source, S & & & & NP1 & fertiliza & on dose & & & & \\
\hline & Do & $D_{1}$ & $\mathbf{D}_{2}$ & $\mathbf{D}_{3}$ & Mean & Do $_{0}$ & $D_{1}$ & $\mathbf{D}_{2}$ & $\mathbf{D}_{3}$ & Mean \\
\hline & & & & Fe-c & ntent & & & & & \\
\hline & & & In Straw & & & & & n Grain & & \\
\hline Mineral, S1 & 110 & 125 & 132 & 136 & 126 & 57.5 & 63.9 & 75.2 & 78.1 & $68.7 \mathrm{~b}$ \\
\hline Nano, S2 & 110 & 129 & 135 & 139 & 128 & 57.4 & 78.2 & 82.1 & 85.3 & $75.8 \mathrm{a}$ \\
\hline Mean & $110 \mathrm{~b}$ & $127 \mathrm{a}$ & 134. a & $138 \mathrm{a}$ & & $57.5 \mathrm{c}$ & $71.1 \mathrm{~b}$ & $78.7 \mathrm{a}$ & $81.7 \mathrm{a}$ & \\
\hline F-test & S: & NS & D: & $* *$ & & S: & $* *$ & D: & $* *$ & \\
\hline & & & SD: NS & & & & & SD: ** & & \\
\hline & & & & Mn- & ontent & & & & & \\
\hline & & & In Straw & & & & & n Grains & & \\
\hline $\mathrm{S} 1$ & 40.3 & 43.3 & 44.9 & 46.3 & $43.7 \mathrm{~b}$ & 29.3 & 32.6 & 35.5 & 37.3 & $33.7 \mathrm{~b}$ \\
\hline S2 & 40.3 & 46.8 & 49.2 & 51.1 & $46.8 \mathrm{a}$ & 29.6 & 38.1 & 42.0 & 43.1 & $38.2 \mathrm{a}$ \\
\hline Mean & $40.3 \mathrm{~b}$ & $45.0 \mathrm{c}$ & $47.1 \mathrm{~b}$ & $48.7 \mathrm{a}$ & & $29.5 \mathrm{~d}$ & $35.3 \mathrm{c}$ & $38.7 \mathrm{~b}$ & $40.2 \mathrm{a}$ & \\
\hline & S: & $* *$ & D: & $* *$ & & S: & $* *$ & D: & $* *$ & \\
\hline F-test & & & $\mathrm{SD}: * *$ & & & & & SD: $*$ & & \\
\hline & & & & Zn-c & ntent & & & & & \\
\hline & & & In Straw & & & & & n Grains & & \\
\hline S1 & 21.4 & 24.4 & 28.3 & 34.1 & $27.1 \mathrm{~b}$ & 33.5 & 36.2 & 38.5 & 39.2 & $36.8 \mathrm{~b}$ \\
\hline S2 & 21.6 & 29.4 & 33.0 & 34.9 & $29.7 \mathrm{a}$ & 33.4 & 39.6 & 40.2 & 41.3 & $38.6 \mathrm{a}$ \\
\hline Mean & $21.5 \mathrm{~d}$ & $26.9 \mathrm{c}$ & $30.7 \mathrm{~b}$ & $34.5 \mathrm{a}$ & & $33.5 \mathrm{~b}$ & $37.9 \mathrm{a}$ & $39.3 \mathrm{a}$ & $40.3 \mathrm{a}$ & \\
\hline F-test & S: & $* *$ & D: & $* *$ & & S: & $* *$ & D: & $* *$ & \\
\hline & & & $\mathrm{SD}: * *$ & & & SD: & & $\mathrm{N}$ & & \\
\hline
\end{tabular}

See footnote of Table 2 .

\section{Yield of protein}

Protein yield ranged from 173 by the nonfertilized mineral $S_{1} D_{0}$ to 360 by the highest fertilized nano $S_{2} D_{3}$ causing $108 \%$. Increased fertilization was accompanied with increased protein uptake and there was no difference between the two sources (Table 3).

Protein content in cereal grain crops respond to application of NPK (Siam, et al. 2013). Other researchers reported positive effects on plant protein as a result of applying NPK (Abedi et al. 2010 and Rana et al. 2012).
Macro and micronutrients content and uptake by straw and grains.

Tables 4 to 7 show status of N, P, K, Fe, Mn, Zn and $\mathrm{Cu}$ in maize grains and straw as affected by application of NPK fertilizers in the two forms of ordinary mineral and nano fertilizers. With regard to the contents, results (particularly in the straw component) show increases with fertilizer application, due to application of fertilizers.

However, regarding the uptake, the pattern of response was rather similar to that of the yield, since the uptake is mainly a function of the yield quantity in the first place. 
Table 6. Macronutrients uptake $\left(\mathrm{kg} \mathrm{ha}^{-1}\right)$ by straw and grains of maize plants

\begin{tabular}{|c|c|c|c|c|c|c|c|c|c|c|}
\hline \multirow{2}{*}{ NPK-source, $S$} & \multicolumn{10}{|c|}{ NPK fertilization dose (D) } \\
\hline & $\mathbf{D}_{0}$ & $\mathbf{D}_{1}$ & $\mathbf{D}_{2}$ & $\mathbf{D}_{3}$ & Mean & Do & $\mathbf{D}_{1}$ & $\mathbf{D}_{2}$ & $\mathbf{D}_{3}$ & Mean \\
\hline \multicolumn{11}{|c|}{ N-uptake } \\
\hline & \multicolumn{5}{|c|}{ In Straw } & \multicolumn{5}{|c|}{ In Grains } \\
\hline Mineral, S1 & 44.2 & 87.3 & 102 & 103 & $84.1 \mathrm{~b}$ & 27.6 & 44.6 & 50.7 & 55.7 & 44.7 \\
\hline Nano, S2 & 45.3 & 115 & 123 & 133 & $104 \mathrm{a}$ & 25.9 & 48.3 & 51.8 & 57.6 & 45.9 \\
\hline Mean & $44.8 \mathrm{~b}$ & $101 \mathrm{a}$ & $113 \mathrm{a}$ & $118 \mathrm{a}$ & & $26.7 \mathrm{~b}$ & $46.5 \mathrm{a}$ & $51.2 \mathrm{a}$ & $56.7 \mathrm{a}$ & \\
\hline \multirow[t]{2}{*}{ F-test } & S: & $* *$ & $\mathrm{D}:$ & $* *$ & & $\mathrm{~S}:$ & NS & $\mathrm{D}:$ & $* *$ & \\
\hline & \multicolumn{5}{|c|}{ SD: NS } & \multicolumn{5}{|c|}{ SD: NS } \\
\hline \multicolumn{11}{|c|}{ P- uptake } \\
\hline & \multicolumn{5}{|c|}{ In Straw } & \multicolumn{5}{|c|}{ In Grains } \\
\hline S1 & 5.89 & 11.0 & 14.0 & 16.1 & $11.8 \mathrm{~b}$ & 7.95 & 12.0 & 15.1 & 17.7 & $13.2 \mathrm{~b}$ \\
\hline S2 & 5.86 & 15.6 & 19.0 & 22.7 & $15.8 \mathrm{a}$ & 8.03 & 13.9 & 16.3 & 18.9 & $14.3 \mathrm{a}$ \\
\hline \multirow[t]{2}{*}{ Mean } & $5.88 \mathrm{c}$ & $13.3 \mathrm{~b}$ & $16.5 \mathrm{ab}$ & $19.4 \mathrm{a}$ & & $7.99 \mathrm{c}$ & $13.0 \mathrm{bc}$ & $15.7 \mathrm{ab}$ & $18.3 \mathrm{a}$ & \\
\hline & S: & $* *$ & D: & $* *$ & & S: & $*$ & D: & $* *$ & \\
\hline F-test & \multicolumn{5}{|c|}{ SD: * } & \multicolumn{5}{|c|}{ SD: NS } \\
\hline \multicolumn{11}{|c|}{ K-uptake } \\
\hline & \multicolumn{5}{|c|}{ In Straw } & \multicolumn{5}{|c|}{ In Grains } \\
\hline S1 & 56.3 & 98.3 & 113 & 115 & $95.6 \mathrm{~b}$ & 20.8 & 29.6 & 34.9 & 39.1 & $31.1 \mathrm{~b}$ \\
\hline S2 & 58.9 & 124 & 133 & 146 & $116 \mathrm{a}$ & 19.2 & 34.4 & 36.8 & 41.7 & 33.0 \\
\hline Mean & $57.6 \mathrm{~b}$ & $111 \mathrm{a}$ & $123 \mathrm{a}$ & $130 \mathrm{a}$ & & $20.0 \mathrm{~b}$ & $32.0 \mathrm{a}$ & $35.9 \mathrm{a}$ & $40.4 \mathrm{a}$ & \\
\hline & S: & $*$ & $\mathrm{D}:$ & $* *$ & & S: & NS & D: & $* *$ & \\
\hline F-test & & & SD: NS & & & SD: & & $\mathrm{N} s$ & & \\
\hline
\end{tabular}

See footnote of Table 2 
Table 7. Micronutrients uptake ( $\left.\mathrm{g} \mathrm{ha}^{-1}\right)$ by straw and grains of maize plants

\begin{tabular}{|c|c|c|c|c|c|c|c|c|c|c|}
\hline \multirow{2}{*}{ NPK-source, S } & \multicolumn{10}{|c|}{ NPK fertilization dose (D) } \\
\hline & $\mathbf{D}_{\mathbf{0}}$ & $\mathbf{D}_{1}$ & $\mathbf{D}_{2}$ & $\mathbf{D}_{3}$ & Mean & $\mathbf{D}_{0}$ & $\mathbf{D}_{1}$ & $\mathbf{D}_{2}$ & $\mathbf{D}_{3}$ & Mean \\
\hline \multicolumn{11}{|c|}{ Fe-uptake } \\
\hline & \multicolumn{5}{|c|}{ In Straw } & \multicolumn{5}{|c|}{ In Grains } \\
\hline Mineral, S1 & 295 & 551 & 661 & 683 & $548 \mathrm{~b}$ & 134 & 197 & 258 & 288 & $219 b$ \\
\hline Nano, S2 & 300 & 694 & 755 & 831 & $645 \mathrm{a}$ & 128 & 259 & 280 & 317 & $246 \mathrm{a}$ \\
\hline Mean & $297 \mathrm{~b}$ & $623 \mathrm{a}$ & 708 a & 757 a & & $131 \mathrm{c}$ & $228 \mathrm{~b}$ & $269 \mathrm{ab}$ & $303 \mathrm{a}$ & \\
\hline \multirow[t]{2}{*}{ F-test } & S: & $*$ & $\mathrm{D}:$ & $* *$ & & S: & $*$ & $\mathrm{D}:$ & $* *$ & \\
\hline & \multicolumn{5}{|c|}{ SD: NS } & \multicolumn{5}{|c|}{ SD: NS } \\
\hline \multicolumn{11}{|c|}{ Mn- uptake } \\
\hline & \multicolumn{5}{|c|}{ In Straw } & \multicolumn{5}{|c|}{ In Grains } \\
\hline S1 & 108 & 191 & 225 & 233 & $189 \mathrm{~b}$ & 68.5 & 100 & 122 & 138 & $107 \mathrm{~b}$ \\
\hline S2 & 110 & 252 & 275 & 305 & $236 \mathrm{a}$ & 66.0 & 126 & 143 & 160 & $124 \mathrm{a}$ \\
\hline Mean & $109 \mathrm{~b}$ & $221 \mathrm{a}$ & $250 \mathrm{a}$ & $269 a$ & & $67.3 \mathrm{c}$ & $113 \mathrm{~b}$ & $132 \mathrm{ab}$ & $149 \mathrm{a}$ & \\
\hline \multirow{2}{*}{ F-test } & S: & $* *$ & D: & $* *$ & & S: & $*$ & $\mathrm{D}:$ & $* *$ & \\
\hline & \multicolumn{5}{|c|}{ SD: NS } & \multicolumn{5}{|c|}{ SD: ** } \\
\hline \multicolumn{11}{|c|}{ Zn-uptake } \\
\hline & \multicolumn{5}{|c|}{ In Straw } & \multicolumn{5}{|c|}{ In Grains } \\
\hline S1 & 57.3 & 108 & 142 & 171 & $119 \mathrm{~b}$ & 78.3 & 111 & 132 & 145 & 117 \\
\hline S2 & 58.9 & 158 & 185 & 209 & $153 \mathrm{a}$ & 74.5 & 131 & 137 & 154 & 124 \\
\hline Mean & $58.1 \mathrm{~d}$ & $133 \mathrm{c}$ & $163 \mathrm{~b}$ & $190 \mathrm{a}$ & & $76.4 \mathrm{~b}$ & $121 \mathrm{a}$ & $134 \mathrm{a}$ & $149 \mathrm{a}$ & \\
\hline \multirow{2}{*}{ F-test } & S: & $* *$ & D: & $* *$ & & S: & NS & D: & $* *$ & \\
\hline & \multicolumn{5}{|c|}{ SD: NS } & SD: & \multicolumn{4}{|c|}{ NS } \\
\hline
\end{tabular}

See footnote of Table 2

\section{CONCLUSION}

The current study shows that using nano forms of fertilizers can cause significant improvement in the efficiency of the use of NPK fertilizers. Nanotechnology can also help in improvement of crop plants grown under salinity stress. (De Rosa et al., 2010).

\section{REFERENCES}

Abdel Wahab, M.M.; El-attar, A.B. and Mahmoud, A.A. (2017). Economic evaluation of nano and organic fertilizers as an alternative source to chemical fertilizers on Carum carvi L. plant yield and components. Agric. (Pol'nohospodárstvo), 63(1): 33-49.

Abedi, T., Alemzadeh A. and Kazemeini, S.A. (2010). Effect of organic and inorganic fertilizers on grain yield and protein banding pattern of wheat. Australian J. Crop Sci., 4(6): 384-389.
Abou El-Yazeid, A. and Abou-Aly, H.E. 2011. Enhancing growth, productivity and quality of tomato plants using phosphate solubilizing microogranisms. Australian J. Basic and Applied Sci., 5(7): 371 - 379.

Ahmed, M.S., Mohamed, M.G. and Gmal, A.E. (2014). Evaluating aqua crop model to improve crop water productivity at North Dalta Soils, Egypt. Adv. Appl. Sci. Res., 5 (5): 293 - 304.

AOAC, (1990). Official Methods of the Association of Official Analysis Chemists (K. Helssch, ed) A.O.A.C. Inc., $15^{\text {th }}$ Edition, Virginia, USA: 9- 64.

Bates, L.S., Waldren, R.P. and Teave, I.D. (1973). Rapid determination of free proline for water stress studies. Plant and Soil, 939: 205-207.

Black,C.A., Evans D.D., White, I.I. Ensminger, L.E. and Clark, F.E. (1982). Methods of soil analysis. Amer. Soc. Agron. Inc., Ser. 9 in Agron., Madison, Wisconsin

Chandra, G. (1989) Nutrients Management. Oxford and IBH Publishing Co., New Delhi, India pp: 156. 
Corradini E., De Moura M.R., Mattoso L.H.C. (2010). A preliminary study of

the incorporation of NPK fertilizer into chitosan nanoparticles. Express Polymer Lett. 4:509-515.

Daneshmand, N.G., Bakhshandeh, A. and Rostami, M.R. (2012). Biofertilizer affects yield and yield components of wheat. Inter. J. Agric. 2(6): 699-704.

De Moura MR, Aouda FA, Mattoso LHC (2008). Preparation of chitosan nanoparticles using methacrylic acid. J. Colloid Interface Sci.321: 477-483.

De Rosa, M.C., Monreal, C., Schnitzer, M., Walsh, R. and Sultan, Y. (2010). Nanotechnology in fertilizers. Nat. Nanotechnol., 5(2): 91.

Ditta, A. (2012). How helpful is nanotechnology in agriculture? Advances in Natural Sciences: Nanoscience and Nanotechnology. 3: 10.

Ekinci, M., Dursun, A., Yidirim, E. and Parlakova, F. (2014). Effects of nanotechnology liquid fertilizers on the plant growth and field of cucumber (Cucumis sativus L.). Acta Sci. Pol., Hortorum Cultus, 13(3): 135 - 141.

El-Bana, A.Y.A. and Gomaa, M.A. (2000). Effect of N and K fertilization on maize grown in different populations under newly reclaimed sandy soil Zagazig J. Agric. Res., 27(5): 1179 - 1190.

El-Shimy, G. H.; M. M. M. Hussein and A. M. M. El-Refaie. (2006). Effect of Nofatrin ( $\mathrm{N}$ - biofertilizer) application times on yield and yield components of some flax verities. J. Agric. Sci., Mansoura Univ., 31 (6): 3295 - 3307.

Ewees, M.S.A. and Abdel Hafeez, A.A.A. (2010). Response of maize grain yield to a partial substitution of $\mathrm{N}$-mineral by applying organic manure, bio-inoculation and elemental sulphur as an alternative strategy to avoid the possible chemical pollution. Egypt J. Soil Sci., 50(1): 141 $-166$.

FAO, (2003). Food energy-methods of analysis and conversion factors. Report of a Technical Workshop. Food and Nutrition Paper, 77:7 - 11, Rome, 3 - 6 December, 2002.

FAO, (2008). Land and Plant Nutrition Management Service. Rome: FAO of UN.

Gad, N. (2005). Interactive effect of salinity and cobalt on tomato plants. II. Some physiological parameters as affected by cobalt and salinity. Res. J. Agric. Sci., 1: 270276.

Jackson, M.L. (1958). Soil Chemical Analysis. Prentice- Hall, Inc., Englewood Califfs, New Jersy .

Haque, S.A (2006). Salinity problems and crop production in coastal regions of Bangladesh. Pak. J. Bot. 38: 13591365.

Hussein, M.M.M. (2007). Response of some flax genotypes to bio and nitrogen fertilization. Zagazig J. Agric. Res., 34 (5): $815-844$.

Kandil, A.A., El-Hindi, M.H., Badawi, M.A., El-Morarsy, S.A. and Kalboush, F.A.H.M. (2011). Response of wheat to rates of nitrogen, biofertilizers and land leveling. Crop and Enviro. 2(1): 46-51.
Mabrouk, S.S. (2002). Response of some peanut cultivars to bio and organo-mineral fertilization. Zagazig J. Agric. Res., 29(6): 2071 - 2083.

Mahmoud A.W.N., (2012). Physiological effects of zeolite and organic fertilizers on yarrow plant grown under clean agricultural conditions. PhD. Thesis, Plant Physiology Department, Fac. Of Agriculture, Cairo Univ., Cairo, Egypt.

Mahmut, D. (2011). Antioxidative and proline potentials as a protective mechanism in soybean plants under salinity stress. Afric. J. Biot. 10 (32): 5972- 5978.

Merghany, M.M., Shahein, M.M., Sliem, M.A., Abdelgawad, K.F. and Radwan, A.F. (2019). Effect of nano-fertilizers on cucumber plant growth, fruit yield and its quality. Plant Archives, 19(2): 165 - 172 .

Moussa, H.R. and Abdel-Aziz, S.M. 2008. Comparative response of drought tolerant and drought sensitive maize genotypes to water stress. Australian Journal of Crop Science 1: 31-36

Mousavi S.R. and Rezaei, M. (2011). Nanotechnology in agriculture and food production. J. Applied Environmental and Biological Sci., 1(10): 414-419.

Namvar, A. and Teymur, K. (2013). Response of wheat to mineral nitrogen fertilizer and biofertilizer (Azotobacter sp. and Azospirillium sp.) inoculation under different levels of weed interference. Ekologija J. 59(2): 85 - 94.

Nofal, F. and Hinar, A. (2003). Growth and chemical properties of maize grow of some single crosses as affected by nitrogen and manure fertilization under sprinkler irrigation in a sandy soil. Egypt. J. Appl. Sci.; 18 (5 B): 583- 596.

Omran, S.E.H., Mohamed, E.A.I. and El-Gpaly, A.H. (2009). Influence of organic and biofertilization on productivity, viability and chemical components of Flax seeds. Egypt. J. Soil Sci., 49 (1): 49 - 64.

Page, A.L., Miller, R.H. and Keeney, D.R. (1982). "Methods of Chemical Analysis". Part 2: Chemical and microbiological properties (Second Edition). American Society of Agronomy, Inc. and Sci. Soc. of America, Inc. Publishers, Madison, Wisconsin U.S.A.

Piper, C.S. (1950). "Soil and Plants analysis." A monograph from the water. Agric. Res. Inst., Univ. of Alediade, Australia.

Rana, A., Joshi, M., Prasanna, R., Shivay, Y.S. and Nain, L. (2012). Bio-fertification of wheat through inoculation of plant growth promoting rhizobacteria and cyanobacteria. Euro. J. Soil Biology, 50: 118-126.

Roosta, H.R., Safarizadeh M. and Hamidpour, M. (2017). Effect of humic acid contained nano-fertile fertilizer spry on concentration of some nutrient elements in two lettuce cultivars in hydroponic system. J. Sci. and Tech. of Greenhouse Culture, 7(28): 51 - 58.

Ryan, J., Garabet, S., Harmsen, K. and Rashid, A. (1996). “A soil and plant analysis". Manual Adapted for the West Asia and North Africa Region. ICARDA, Aleppo, Syria, 140 . 
Siam, H.S., Shaban, Kh.A. And Safaa, A.M. (2013). Evaluation of applying different mineral nitrogen sources on soil fertility and wheat productivity under saline soil conditions. J. Applied. Sci. Res., 9(4): 3146 - 3156.

Srilatha B. (2011). Nanotechnology in agriculture. J. Nanomed. Nanotech., 2: 5-7.

Snedecor, G.W. and Cochran, W.G. (1971). Statistical Methods $6^{\text {th }}$ eddition. Iowa State University Press, Ames. Iowa, U.S.A.
Subbaiya, R.; Priyanka, M. and Selvam, M. (2012). Formulation of green nano-fertilizer to enhance the plant growth through slow and sustained release of nitrogen. J. Pharmacy Res., 5(11): 5178-5183.

Vessey, J.K. (2003). Plant growth promoting rhizobacteria as biofertilizers. Plant and Soil. 255:571-586.

Witham, F.H., Blaydes, D.F. and Devin, P.M. (1971). Experiments in plant physiology. Van Nosland Reihold. Co. New York, 55-58.

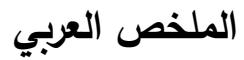

\section{تأثير أسمدة النيتروجين والفففور والبوتاسيوم في صورتي النانو والمعدنيه العاديه علي نمو نباتات الذرة الثامية (Zea mays L.) المزروعة في ارض مل فيونية صودية}

$$
\text { ساره السيد السيد فوده }
$$

تسميدها بالصورة النانوية كانت أحسن تأثيرا وأفضل بصورة كبيرة من تلك التي أستخدم التسميد فيها بالصورة المعدنية التقليدية. كانت الأفضلية بنسبة م و ץ ( ٪ زيادة في محصول القش والحبوب علي التوالي. بالنسبة للقياسات الأخري كانت

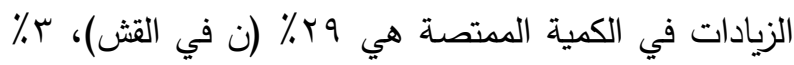

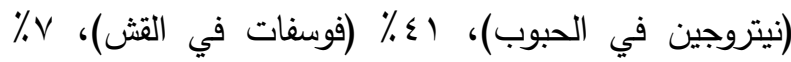

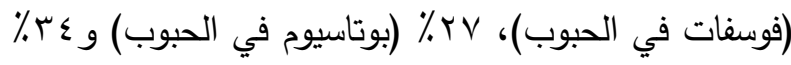
(بوتاسيوم في الحبوب). أدي التسميد إلي تحسين مقاومة النباتات لظروف الإجهاد الملحي بالتربة. أدي التسميد المعدني إلي زيادة تراكم البرولين بالنباتات بالأجزاء الطازجة

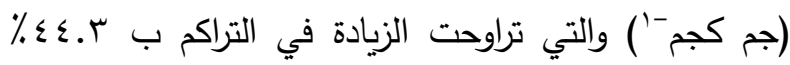

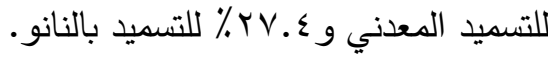

تم دراسة تأثيرالتسميد بأسمدة النيتروجين والفسفور والبوتاسيوم من مصادر نانونية مقارنة بالتسميد المعدني على

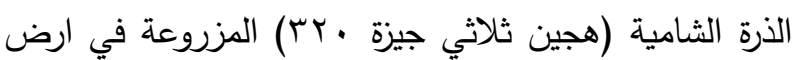
ملحية صوديه بقرية رمانه، محافظة شمال سيناء - جمهورية

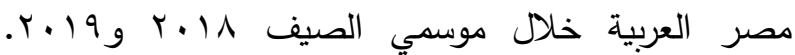
تصميم التجربة أستخدم فيه تصميم القطاعات المنشقة كاملة العشوائية والتي تحتوي علي عاملين للدراسة وهما: العامل الأول مصادر التسميد ويحتوي علي مصدرين هما المعدني S1 والنانو S2 والعامل الثاني هو معدلات التسميد وهي

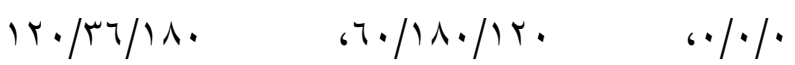

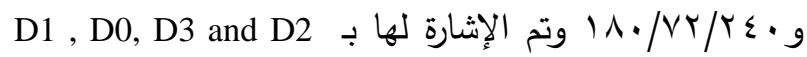

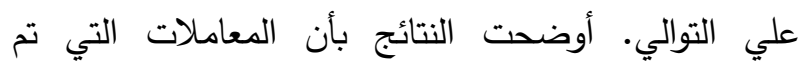

